\title{
Voice from the 'Other': A Feminist Reading of Doris Lessing's The Summer Before the Dark
}

Murugesan M

Research Scholar (Part-Time)

Virudhunagar Hindu Nadars' Senthikumara Nadar College (Autonomous)

Virudhunagar, Tamil Nadu, India

mohanrajenglish@gmail.com

Dr. A. K. Muthusamy

Associate Professor of English

Research Centre in English

Virudhunagar Hindu Nadars' Senthikumara Nadar College (Autonomous)

Virudhunagar, Tamil Nadu, India

DOI: https://doi.org/10.24113/ijellh.v9i4.10992

Thus humanity is male and man defines woman not in herself but as relative to him, she is not regarded as an autonomous being ... She is defined and differentiated with reference to man and not he with reference to her, she is the incidental, the inessential as opposed to the essential. He is the Subject, he is the Absolute -She is the other (Beauvoir346)

\section{Abstract:}

The concept 'the Other' is a literary theory, which defines one's identity among others. It explains the state of a person who is neglected or subordinated and displays how one feels as an alien by gender, caste, religion, culture, appearance, geography, ideology and so on. Doris 
Lessing's novels are mostly concerned with human race and criticize the patriarchal society, where female does not get the recognition she is due. Instead of taking care of women, appreciating their talents and providing them freedom of expression and movement, the society makes them feel 'the Other'. Lessing has crafted the novel, The Summer Before the Dark as to expose the fate of women, who are always submissive and unassertive to their husbands and children, thereby becoming insignificant to the society. This paper examines the status of Kate Brown in her family and in the society, where she is neglected and deprecated by her ungrateful husband and children by the frame of 'The Other'/ 'Otherness'. Keyterms -Neglected, Otherness, the other and Self-identity

Doris Lessing is the most widely acclaimed and highly honoured Nobel Prize winning British novelist. She began her literary career with her debut novel The Grass is Singing in 1950. Though her oeuvre consists of wide range of topics, her novels are classified into two types: 'inner space' and 'outer space' novels. Mostly, Lessing explores the status of female as a housewife, and a writer, in society as well as in politics. Her novel The Grass is Singing defines the status of a woman, Mary Turner as a wife of an African farmer, Dick Turner and her troubled psyche in an alien country. The Golden Notebook describes a divorced woman in politics and writing phase. In Martha Quest, Martha is portrayed as a woman of selfdiscovery and Love, Again revolves around an aged widow, Sarah and her relationship with a young boy.

The novel The Summer Before the Dark (1973) focuses the destiny of forty-five years old Kate Brown who is a wife of Michael and the mother of three children. After being a devoted wife for twenty years, Kate finds herself in precarious position. Her family members do not have confidence in her ability to solve problems and so they have made decision without consulting her. Her husband is planning to visit Britain along with her grown-up daughter. Her two sons have their own plan to execute as they have decided to take off 
another country for higher studies and job. Their plan of renting out their house forces her to stay away. She feels "unnecessary" (Lessing 23). She is belittled by her family. She is almost a non-entity in her family. In The Second Sex Beauvoir talks about the women's restrictions and norms which were created by men and society. She states that "A girl's free choice was highly restricted" (451). Kate's family has restricted her from moving along with her husband and children. She is forced to leave her home and join in a Global Food Company as a translator by her husband.

Kate gets awakened from her passive attitude and starts her journey of self-discovery when she is never included in a summer plan of her husband and children. Kate is left alone in her home country. While they live together as a family, Kate is always submissive and serves as a caretaker, nutritionist and pleasure giver to her husband. She invariably depends on her family members both financially and socially. But her husband and her grown children have failed to show their care and love towards her. Even they have never encouraged her work. Kate is alienated and isolated. Without her family and house she starts her career as a translator of Global Food Company. She visits Spain with young lover Jeffery, comes back to London and spends her days with Moureen who is in her daughter Ellien's age. Finally, she reaches her home as the bird returns to its cage.

The term 'the Other' is used in the study of post-colonial and feminist literary criticism in order to expose one's social identity. The identity may differ by the biological difference between men and women, status, religious, politics and society. The concept 'the Other' is used by the Second-wave feminist, Simone de Beauvoir in her book The Second Sex. She has evolved the concept to explicate the working of Man-Woman gender relation on the basis of the Dominator-Dominated. Lister defines the concept of 'the Other' as a "process of differentiation and demarcation, by which the line is drawn between 'us' and 'them'... between the more and less powerful ... And through which social distance is 
established and maintained" (101).Beauvoir has also developed the concept of 'Otherness'. Otherness seeks to scrutinize the construction of majority identities and minority identities. She argues that female identity is constructed by males to suit their welfare, thereby presenting women as the other sex. In feminists study, 'the Other / Otherness' is used to describe how the society and men make female feel inferior by ignoring or neglecting both socially and psychologically. A dominant in-group formulates 'the Self' whereas many dominated out-groups construct 'the Other'. Feminist are of the view that man is called 'the Self' and woman as 'the Other'. According to Simone de Beauvoir no man is set up as the other of man. This social construct stigmatizes a difference leading to gender discrimination.

With the traditional social system, themale-dominated society suppresses women and keeps them as subordinate. This discrimination and the social norms create the mental pressure on female psyche resulting women propelling to seek self-identity. The Summer Before the Dark commences with the third person's description upon Kate Brown as “A woman stood on her back step, arms folded, waiting. Thinking she would not have said so. She was trying to catch hold of something" (Lessing 3).The champion of feminism, Mary Wollstonecraft in her trailblazing feminist essay "A Vindication on the Rights of Women" (1792) argues that education could create emancipation of women. She criticizes the educational system that has purposefully trained women to be insignificant and incapable and insists that girls must be given the same level of education as boys so that they can prove their excellences. Though Kate is good at Portuguese, Spanish, Italy and English she is not allowed to pursue further. The patriarchal society sets its own standard for women and simply handover to men in the name of marriage. The society demands her to get married. Kate sacrifices her education. To her "marriage is a compromise" (Lessing 3) and is a crucial need for a woman. She prefers to marry Michael, a doctoral employer. The traditional 
responsibility of the married woman is to care taker of the child and other members of the family.

Wearing clothes plays an important role in women's life. Kate wants to dress like Mary, a neighbour but she has to restrain the wish. Due to traditional customs and having adulthood children, she does not choose such type of dresses and uses formal dress Kamala Das in her poem "An Introduction" describes the pathetic condition of women by dresses."Dress in sarees, be girl/ be wife, they said. Be embroider be cook" (35-37). Its marks as "she did not allow her appearance to bloom, because she had observed early in the children's adolescence how much they disliked her giving rein to her own nature"(Lessing 10). She seeks employment in an international Global Food Company. She has to change her appearance as a sexually attracted woman. Her profession requires flirting dress to attract the attention of men. In Global Food Company, she feels as 'The Other' because she is more imposed to have attractive and pleasing appearance even in the age of forty. She is identified as a public sexual figure of the company.

Kate's journey into business life creates a phase for self-realization and enters into a new relationship with younger Jeffery and travels to Spain. Before she accepts the invitation of Jeffery she looks back her past life as a housewife where she feels completely unnoticed, alien and longing for caring. "When she looks back, would seem to her all dryness and repetition"(Lessing 68). Now she realises that since her marriage she has been playing a role of insignificance in her family. Her affairs with Jeffrey helps her notice her individuality.

In Spain, as soon as Jeffery is in sick-bed, she thinks herself as alien and longs to join with her family. She returns to England, but she is not able to visit her home. She stays in a mansion with Moureen, an independent girl. Now again, unaffectionate, she is not noticed by everyone because of her unfit dresses, dizzy hair and her unattractive structure. When she is in London, she is treated as invisible but Kate flaunts a fitting dress with styling hair, she 
attracts the attention of men and women. The society gives important to the external charismatic of females, so now Kate feels alien to the society. But Kate demands warm and concern from everyone but she gets disappointment.

The novel The Summer Before the Dark examines the importance and the psychological conditions of a woman and explores how the patriarchal society is adamant in treating women unequally. Beauvoir in The Second Sex believes that the women's liberation and the role of mother cannot coexist and emphasizes that birth is the direct cause of enslavement of women. Throughout the novel, Kate is being ignored by family and society. Her neighbour fails to take notice of her and even as a waitress in a restaurant ignores her which makes her feel invisible. Her pitiable condition is revealed in the following words:

She sat by herself and waited for service ... a waitress was talking to a customer ... when she did come she did not look at take, but scribbled the order down hastily on a small pad, and went back to talk to the customer ... It seemed a long time before the foo came. Kate sat on invisible, apparently, to the waitress and to the other customers: the place was filling now. She was shaking with impatient hunger, the need to cry. The feeling that no one could see her made her want to shout: 'Look, I'm here, couldn't you see me?' She was not far of the state which in a small child is called a tantrum. (Lessing 188)

Kate Brown spends her entire life serving her family but her familial dutyis never recognized and valued. She feels lonely. They never pay attention to her as a person of the family. When she comes back home from Spain, the society also fails to consider her. Even the servant maid of a restaurant refuses to server her because of her older physical appearance. A woman is allowed to marry only to serve her husband, rear her children and support her grandchildren. This social disparity makes women feel inferior or 'The Other'. 
Women fail to choose their life and achieve their destination. In the novel The Summer Before the Dark, Kate also fails to choose her independent life. She says that “. . . some course of action I could choose. . Choose? When do I ever choose? Have I ever choosen?" (Lessing 9). Culturally and socially males and traditions do not allow women to do anything as per their desires. As a woman writer Doris Lessing has carefully crafted the fate of Kate.

Gender inequality and power manipulation in family and society make woman as 'The Other' or inferior or subordinate. Women are suppressed not only by men but also other women in their own family, as in the case of Kate whose husband, sons and daughter do not consider her as their equals. 'The Other'/'Otherness' focuses on how people treat other human as very differently and ignore them as frivolous. 


\section{Works Cited}

Beauvoir, Simon De. The Second Sex. Trans. Constance Bonde and Sheila Malovary, Vintage Books, 2001.

Das, Kamala. “An Introduction.” Poem Hunter, www.poemhunter.com/poem/anintroduction-2/. Accessed 17 Oct. 2020.Gunn, Giles. The Interpretation of Otherness. Oxford UP, 1979.

Hao, Ningning. "A Feminist Study of The Summer before the Dark."Theory and Practice in Language Studies, vol. 7, 2017. pp. 677 - 681, DOI:

dx.doi.org/10.17507/tpls.0708.10. Accessed 20 May 2020.

Lessing, Doris. The Summer Before the Dark. Vintage International, 1973.

Lister, Ruth. Poverty.Combridge Polity Press, 2004.

Susan, M. Klein. "First and Last Words: Reconsidering the title of The Summer Before the Dark". Critique: Studies in Contemporary Fiction, 43.3, 26. March. 2010, pp. 228 238, DOI: doi/abs/10.1080/00111610209602182. Accessed 11 May 2020. 